\title{
Agrococcus casei sp. nov., isolated from the surfaces of smear-ripened cheeses
}

\author{
Nagamani Bora, ${ }^{1}$ Marc Vancanneyt, ${ }^{2}$ Roberto Gelsomino, ${ }^{2}$ Jean Swings, ${ }^{2,3}$ \\ Noelle Brennan, ${ }^{4}$ Timothy M. Cogan, ${ }^{4}$ Sandra Larpin, ${ }^{5}$ \\ Nathalie Desmasures, ${ }^{5}$ Frieda Eliskases Lechner, ${ }^{6}$ \\ Reiner M. Kroppenstedt, ${ }^{7}$ Alan C. Ward ${ }^{1}$ and Michael Goodfellow ${ }^{1}$ \\ ${ }^{1}$ Division of Biology, King George VIth Building, University of Newcastle, Newcastle upon Tyne \\ NE1 7RU, UK
${ }^{2}$ BCCM/LMG Bacteria Collection, Faculteit Wetenschappen, Ghent University, B-9000 Ghent, Belgium
${ }^{3}$ Laboratorium voor Microbiologie, Faculteit Wetenschappen, Ghent University, B-9000 Ghent, Belgium \\ ${ }^{4}$ Moorepark Food Research Centre, Teagasc, Fermoy, County Cork, Ireland \\ ${ }^{5}$ Laboratoire de Microbiologie Alimentaire, Université de Caen Basse - Normandie, esplanade \\ de-la-paix, 14032 Caen cedex, France \\ ${ }^{6}$ Bundesanstalt für Alpenländische Milchwirtschaft, Rotholz 50a, 6200 Rotholz, Austria \\ ${ }^{7}$ DSMZ - German Collection of Microorganisms and Cell Cultures, Braunschweig, Germany
}

Correspondence Michael Goodfellow m.goodfellow@ncl.ac.uk

\begin{abstract}
Seven Gram-positive, coryneform bacteria with virtually identical whole-organism protein patterns were isolated from the surface of smear-ripened cheeses. Representatives of these strains were the subject of a polyphasic study designed to establish their taxonomic status. The organisms formed a distinct branch in the Microbacteriaceae 16S rRNA gene tree and were most closely related to members of the genus Agrococcus, sharing sequence similarities of 95.4-98.7\%. The chemotaxonomic profiles of the strains were consistent with their classification in the genus Agrococcus. The combined genotypic and phenotypic data show that the isolates should be classified in the genus Agrococcus as representatives of a novel species. The name Agrococcus casei sp. nov. is proposed for this taxon. Isolate R-17892t $2^{\top}\left(=\mathrm{DSM} 18061^{\top}=\mathrm{LMG} 22410^{\top}\right)$ is the type strain of Agrococcus casei sp. nov.
\end{abstract}

The complex consortium of micro-organisms found on the surfaces of smear-ripened cheeses includes major populations of coryneform bacteria (catalase-positive irregular rods and cocci), staphylococci (catalase-positive cocci) and yeasts (Valdés-Stauber et al., 1997; Carnio et al., 1999; Bockelmann \& Hoppe-Seyler, 2001). Until recently, cheese coryneform bacteria were assigned to groups based on a few subjectively weighted morphological and staining properties (Piton-Malleret \& Gorrieri, 1992; Eliskases-Lechner \& Ginzinger, 1995). Such studies have been replaced by polyphasic taxonomic investigations, which show that the coryneform component of smear-ripened cheeses contains members of novel taxa, as exemplified by the isolation and

Abbreviation: DAB, diaminobutyric acid.

The GenBank/EMBL/DDBJ accession numbers for the 16S rRNA gene sequences of Agrococcus casei LMG 22410' ${ }^{\top}$, LMG 22411, LMG 22330 and LMG 22447 are DQ168427, DQ168426, DQ168425 and D0168424, respectively. description of Corynebacterium casei and Microbacterium gubbeenense from the surface of Gubbeen cheese (Brennan et al., 2001a, b, 2002) and Arthrobacter arilaitensis and Arthrobacter bergerei from diverse French smear-ripened cheeses (Irlinger et al., 2005). The present study was designed to determine the taxonomic status of a homogeneous group of coryneform bacteria isolated from smear-ripened cheeses and presumptively assigned to the genus Agrococcus.

The genus Agrococcus was proposed by Groth et al. (1996) for two Gram-positive, coryneform bacteria that could be distinguished from members of other genera classified in the family Microbacteriaceae using genotypic and phenotypic criteria. The genus currently contains four species with validly described names: Agrococcus baldri Zlamala et al. 2002; Agrococcus citreus Wieser et al. 1999; Agrococcus jenensis Groth et al. 1996; and Agrococcus lahaulensis Mayilraj et al. 2006. These taxa contain organisms isolated from compost soil and sandstone, a medieval wall painting, air and soil, respectively. Members of these species can be 
distinguished using a combination of phenotypic markers and together form a distinct branch in the Microbacteriaceae 16S rRNA gene tree (Wieser et al., 1999; Lin et al., 2004).

Bacteria were isolated from Gubbeen, Livarot and Tilsit cheeses following suspension and homogenization (stomacher; Interscience) of samples of the surfaces of the cheeses in sodium citrate $(2 \%, \mathrm{w} / \mathrm{v})$. Tenfold dilutions were plated onto plate count agar (Biokar Diagnostic) supplemented with $3 \%(\mathrm{w} / \mathrm{v})$ sodium chloride. The isolates were grown for up to 2 days at $30^{\circ} \mathrm{C}$ on tryptic soy broth (TSB; Difco) containing $1.5 \%$ agar (Oxoid). DNA isolation and electrophoresis were done according to Gevers et al. (2001) and rep-PCR was carried out with the primer set BOXAIR according to Versalovic et al. (1994). Band patterns analysed using the Pearson product moment coefficient and the UPGMA clustering algorithm with Bionumerics software (Applied Maths) were compared with a database composed of type and reference strains representing species that are common on the surfaces of smear-ripened cheeses (data not shown). A homogeneous group comprising seven isolates (LMG 22410 ${ }^{\mathrm{T}}$, LMG 22411, LMG 22330, LMG 22447, R21294, R-17921 and R-17924) remained unidentified. The taxonomic position of these isolates was the subject of the present study.

Five strains, LMG $22410^{\mathrm{T}} \quad\left(=\mathrm{DSM} \quad 18061^{\mathrm{T}}=\mathrm{R}-\right.$ $\left.17892 \mathrm{t}^{\mathrm{T}}=\mathrm{BG} 1: 37: 24\right)$, LMG $22411(=\mathrm{R}-17926=\mathrm{BG} 1$ : 37:9), R-21294 (=BG4:L10), R-17921 (=BG1:23: 67) and R-17924 (BG1:37:21), were isolated from Gubbeen cheese, one strain, LMG 22447 (=R$19148=$ BIV-1M43), was from Livarot cheese, and one strain, LMG 22330 (=R-18889=B-Y413), was from Tilsit cheese. Four representative strains, namely isolates LMG 22410 ${ }^{\mathrm{T}}$, LMG 22411, LMG 22330 and LMG 22447, were selected for further study. The reference type strains used in the present study were $A$. baldri LMG $23057^{\mathrm{T}}$ (=DSM $\left.14215^{\mathrm{T}}\right)$, A. citreus LMG $23056^{\mathrm{T}}\left(=\mathrm{DSM} 12453^{\mathrm{T}}\right)$ and $A$. jenensis LMG $23058^{\mathrm{T}}\left(=\right.$ DSM $\left.9580^{\mathrm{T}}\right)$.

The phylogenetic positions of the four representative cheese isolates were determined by $16 \mathrm{~S}$ rRNA gene sequence analysis. Biomass from growth in brain-heart infusion broth (BHI; Difco) for 5 days at $30^{\circ} \mathrm{C}$ was checked for purity, harvested by centrifugation, washed in $\mathrm{NaCl} / \mathrm{EDTA}$ buffer (0.1 M EDTA, $0.1 \mathrm{M} \mathrm{NaCl}, \mathrm{pH} 8.0)$ and stored at $-20^{\circ} \mathrm{C}$ until required. Genomic DNA was extracted as described by Sambrook \& Russell (2001) and used as a template for PCR amplification and sequencing following the procedure of Kim et al. (1998). The resultant almost complete $16 \mathrm{~S}$ rRNA gene sequences (1466-1470 nt) were manually aligned with corresponding sequences of representatives of the genera classified in the family Microbacteriaceae, retrieved from the GenBank and RDP databases, using the pairwise alignment option and 16S rRNA secondary structure information held in the program PHYDIT (available at http://plaza.snu.ac.kr/ $\sim$ jchun/phydit/).
Phylogenetic trees were inferred using the least-squares (Fitch \& Margoliash, 1967), maximum-parsimony (Kluge \& Farris, 1969) and neighbour-joining (Saitou \& Nei, 1987) tree-making algorithms from the PHYLIP suite of programs (Felsenstein, 1993). The distance model of Jukes \& Cantor (1969) was used to generate evolutionary distance matrices for the least-squares and neighbour-joining algorithms. The resultant unrooted tree topologies were evaluated in a bootstrap analysis (Felsenstein, 1985) of the neighbourjoining dataset using the CONSENSE and SEQBOOT options from the PHYLIP package. Phylogenetic analyses showed that the four isolates formed a distinct lineage within the evolutionary radiation occupied by genera classified in the family Microbacteriaceae (Fig. 1). This taxon was most closely related to four representatives of the genus Agrococcus, namely A. baldri, A. citreus, A. lahaulensis and A. jenensis, with $16 \mathrm{~S}$ rRNA gene sequence similarities of 95.4-98.7\%.

The four isolates were the subject of chemotaxonomic studies designed to determine whether they had chemical features that were consistent with their classification in the genus Agrococcus. The strains were grown in BHI broth for 5 days at $30^{\circ} \mathrm{C}$ and the resultant biomass was washed twice in distilled water and freeze-dried. Established methods were used for the extraction and analysis of fatty acids (Komagata \& Suzuki, 1987), muramic acid type (Uchida et al., 1999), polar lipids (Minnikin et al., 1984) and wholeorganism sugars (Schaal, 1985). Qualitative analysis of the amino acids was performed using a standard procedure (Schleifer \& Kandler, 1972; Schleifer, 1985). The peptidoglycan structures of isolates LMG 22411 and LMG 22330 were determined using the DSMZ Identification Service. To this end, quantitative analyses of amino acids of the isolates in total hydrolysates were performed by GC and GC-MS, as described by Mackenzie (1987).

The isoprenoid quinone composition of strain LMG $22410^{\mathrm{T}}$ was determined using modifications of established procedures (Collins \& Kroppenstedt, 1987; Kroppenstedt, 1985). Isoprenoid quinones were extracted from lyophilized cells $(500 \mathrm{mg})$ with chloroform : methanol $(2: 1, \mathrm{v} / \mathrm{v})$ for $2 \mathrm{~h}$ on a magnetic stirrer. The extract was filtered and the cell biomass was re-extracted for another $2 \mathrm{~h}$. Extracts were combined and evaporated (Zymark evaporator) to dryness at $40{ }^{\circ} \mathrm{C}$; the lipids were dissolved in $200 \mu \mathrm{l}$ acetone. Isoprenoid quinones were purified by TLC on Kieselgel $60 \mathrm{~F}_{254}$ plastic-backed TLC sheets (Merck) using the solvent system hexane: diethyl ether $(85: 15, \mathrm{v} / \mathrm{v})$. Isoprenoid quinones were visualized under UV light $(254 \mathrm{~nm})$ and eluted from the TLC plate with diethyl ether. The eluate was dried, dissolved in $200 \mu \mathrm{l}$ 2-propanol and filtered through a $2 \mu \mathrm{m}$ hollow fibre syringe filter (DynaGard). The purified extract $(5 \mu \mathrm{l})$ was analysed by HPLC on a reversed-phase column $(250 \times 4.6 \mathrm{~mm}$ Lichrospher $100 \mathrm{RP}-18$ endcapped; Merck) at $40{ }^{\circ} \mathrm{C}$, eluted with acetonitrile:2-propanol $(65: 35, \mathrm{v} / \mathrm{v})$ at $1 \mathrm{ml} \mathrm{min}^{-1}$ using an HP-1090 HPLC pump (Hewlett Packard) and an HP-1090 diode array 


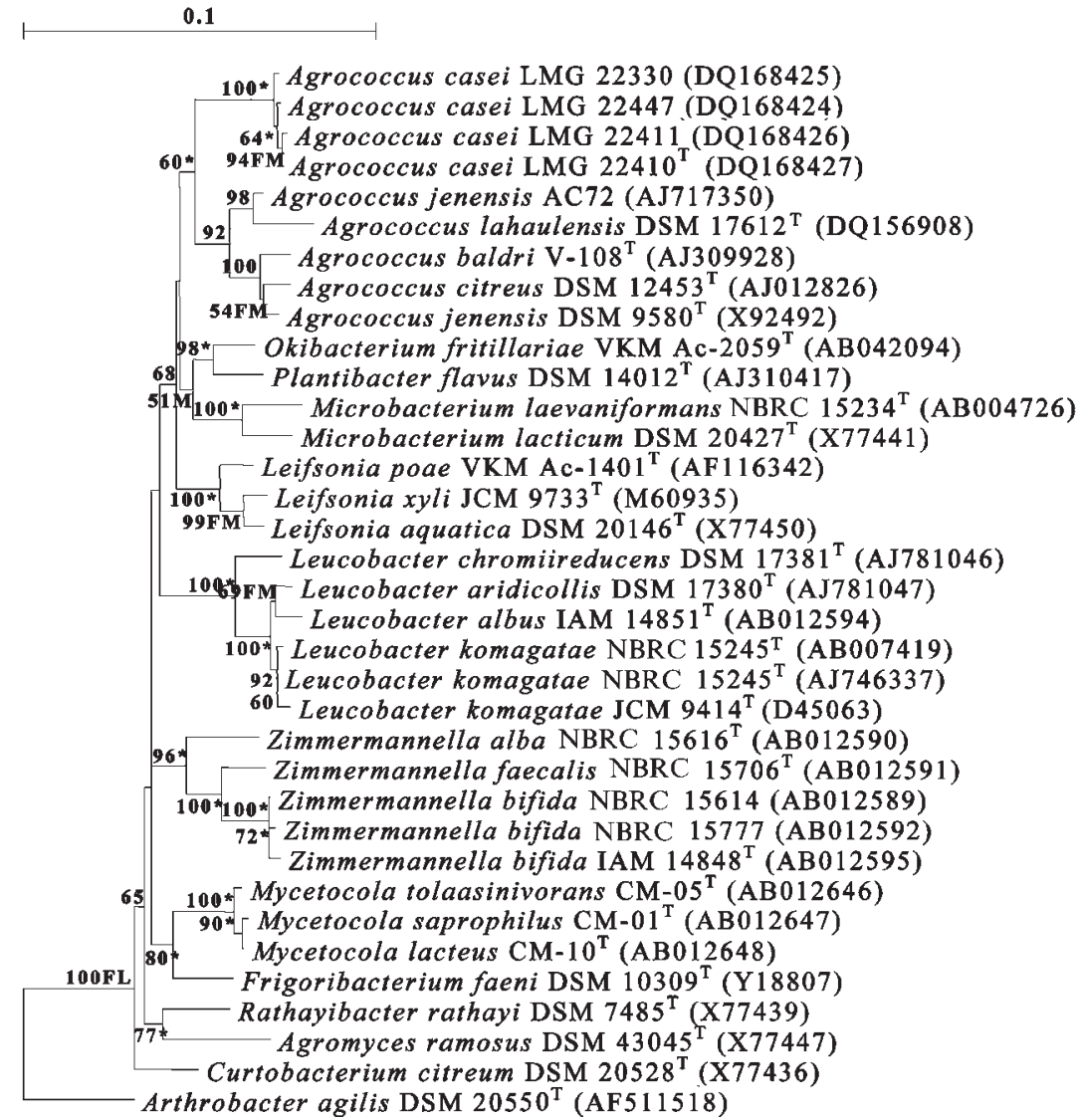

Fig. 1. Neighbour-joining tree (Saitou \& Nei, 1987) based on nearly complete $16 S$ rRNA gene sequences showing the position of representative strains of Agrococcus casei sp. nov. in the Microbacteriaceae gene tree. Asterisks indicate branches of the tree that were also found using the least-squares (Fitch \& Margoliash, 1967), maximumlikelihood (Felsenstein, 1993) and maximumparsimony (Kluge \& Farris, 1969) tree-making algorithms. $\mathrm{F}$ and $\mathrm{M}$ indicate branches recovered using the least-squares and maximum-likelihood methods, respectively. Numbers at the nodes indicate levels of bootstrap support based on a neighbourjoining analysis of 1000 resampled datasets; only values above $50 \%$ are given. Bar, 0.1 nucleotide substitutions per nucleotide position. detector with HP-chemstation software. Isoprenoid quinones were identified by their retention times using bacterial quinone extracts of known composition for comparison. A spectrum of $200-400 \mathrm{~nm}$ at the apex of the peak was determined using a diode array detector.

The four representative isolates contained diaminobutyric acid (DAB) as the wall diamino acid. In addition, alanine, glycine and glutamic acid were detected in the two isolates that were the subject of additional studies. Cell wall Ala:Gly:DAB:Glu ratios were $2.9: 1.3: 0.9: 1.0$ and $1.8: 1.0: 0.7: 1.0$ for strains LMG 22411 and LMG 22330, respectively. The partial hydrolysates of these strains included the peptides Gly-Glu and Ala-Ala, but not LAla-D-Glu. The qualitative amino acid composition of strains LMG 22411 and LMG 22330 corresponded to peptidoglycan type B2 $\gamma$ (Schleifer \& Kandler, 1972). The isolates contained $\mathrm{N}$-acetylated muramic acid. They contained diphosphatidylglycerol, phosphatidylglycerol, an unknown glycolipid and unknown polar lipids as major polar lipids and four unknown phospholipids as minor components. Whole-organism sugars galactose, glucose and mannose were present and menaquinones MK-10 (4\% of total), MK-11 (71\% of total) and MK-12 (20\% of total) were the predominant isoprenologues. The fatty acid profiles of the strains were rich in 12-methyltetradecanoic (anteiso- $\mathrm{C}_{15: 0} ; 44.9-56.1 \%$ of total), 14-methylhexadecanoic (anteiso- $\mathrm{C}_{17: 0} ; 26.9-30.0 \%$ of total) and 13-methyltetradecanoic (iso- $\mathrm{C}_{15: 0} ; 8.2-11.6 \%$ of total) acids, with smaller proportions of 14-methylpentadecanoic acid (iso- $\mathrm{C}_{16: 0}$; $2.9-8.0 \%$ of total $)$ and traces of hexadecanoic acid $\left(\mathrm{C}_{16: 0}\right)$. These chemotaxonomic characteristics are consistent with the classification of the isolates in the genus Agrococcus (Groth et al., 1996; Wieser et al., 1999; Zlamala et al., 2002), but they also suggest that the isolates belong to a separate species.

The DNA G $+\mathrm{C}$ content was determined for strain LMG $22410^{\mathrm{T}}$. DNA was extracted from biomass using the protocol described by Pitcher et al. (1989) modified by lysing the washed cell pellet in $10 \mathrm{mM}$ Tris $/ \mathrm{HCl}$, $100 \mathrm{mM}$ EDTA, pH 8.0, containing RNase $\left(200 \mu \mathrm{g} \mathrm{ml}{ }^{-1}\right.$; Sigma), mutanolysin (100 $\mathrm{U} \mathrm{ml}^{-1}$; Sigma) and lysozyme (25 $\mathrm{mg} \mathrm{ml}^{-1}$; SERVA) for $1 \mathrm{~h}$ at $37^{\circ} \mathrm{C}$, then adding proteinase $\mathrm{K}\left(200 \mu \mathrm{g} \mathrm{ml}^{-1}\right.$; Merck) to the mixture for $15 \mathrm{~min}$ before addition of guanidine isothiocyanate. The DNA was digested enzymically to nucleotides (Mesbah et al., 1989). The nucleotides were analysed by HPLC on a Waters Symmetryshield C8 column maintained at $37^{\circ} \mathrm{C}$ with $0.02 \mathrm{M} \mathrm{NH} \mathrm{NH}_{2} \mathrm{PO}_{4}(\mathrm{pH} 4.0)$ and $1.5 \%$ acetonitrile as eluent; non-methylated $\gamma$-phage DNA (Sigma) was used as the calibration reference. The DNA G $+\mathrm{C}$ content of strain 


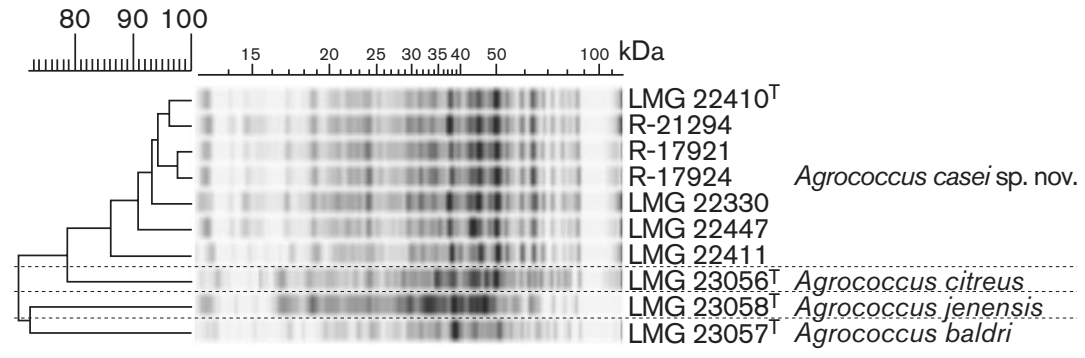

Fig. 2. SDS-PAGE patterns of strains of Agrococcus casei sp. nov. and the type strains of related Agrococcus species. The dendrogram was constructed by the UPGMA linkage of correlation coefficients ( $r$, expressed for convenience as percentage values).
LMG $22410^{\mathrm{T}}$ was $65 \mathrm{~mol} \%$, a figure considerably lower than the values of $74-75 \mathrm{~mol} \%$ reported in the literature for the members of the genus Agrococcus studied here (Groth et al., 1996; Wieser et al., 1999; Zlamala et al., 2002).

SDS-PAGE of whole-organism proteins, a procedure commonly used for species delineation, was performed as a screening procedure to establish relationships between the isolates and A. baldri LMG $23057^{\mathrm{T}}$, A. citreus LMG $23056^{\mathrm{T}}$ and $A$. jenensis LMG $23058^{\mathrm{T}}$. Cultures were grown for $1-2$ days at $30^{\circ} \mathrm{C}$ on TSB containing $1.5 \%$ agar. Wholeorganism protein extracts were prepared and SDS-PAGE was carried out according to Pot et al. (1994). Densitometric analysis, normalization and interpolation of protein profiles and numerical analyses were achieved using the software package GELCOMPAR versions 3.1 and 4.0 (Applied Maths). The isolates formed a homogeneous group that was distinct from that of the Agrococcus type strains studied (Fig. 2).

The representative isolates and type strains of the three Agrococcus species studied were examined for a range of phenotypic properties using standard procedures: acid production from sugars (Hugh \& Leifson, 1953); catalase activity, degradation tests and growth on organic acids as sole carbon sources (Gordon \& Mihm, 1957, 1962); aesculin hydrolysis (Williams et al., 1983); allantoin and urea hydrolysis (Cowan, 1974); nitrate reduction and hydrogen sulphide production (Gordon, 1968); degradation of Tweens (Sierra, 1957); and the breakdown of glycerol tributyrate using tributyrin agar (Sigma). All tests were incubated at $30^{\circ} \mathrm{C}$ for 14 days. API ZYM tests (API bioMérieux) were performed following the manufacturer's instructions. The isolates shared a range of phenotypic properties that enabled them to be distinguished from the Agrococcus type strains studied (Table 1).

It can be concluded from the genotypic and phenotypic data that the newly isolated strains should be classified as representatives of a novel species in the genus Agrococcus. The name proposed for this taxon is Agrococcus casei sp. nov.

\section{Description of Agrococcus casei sp. nov.}

Agrococcus casei (ca.se'i. L. gen. n. casei of cheese, named because the organism was isolated from smear-ripened cheeses).
Aerobic, Gram-positive, asporogenous, non-motile, catalase-positive actinomycete that forms irregular, ovoid to short rods. Cells are $0.3-0.4 \times 0.8-1.0 \mu \mathrm{m}$ and occur singly, in pairs or short chains and in small irregular clusters. Circular, cream-coloured, smooth colonies with entire edges are formed on tryptic soy agar. Grows at $20-30{ }^{\circ} \mathrm{C}$, but not at 4 or $42^{\circ} \mathrm{C}$. Good growth occurs between pH 6.0 and 10.0. Starch is degraded and Tween 80 is hydrolysed. Growth on a range of carbon sources is variable. Additional phenotypic properties are shown in Table 1 . The cell wall diamino acid is DAB; alanine, glycine and glutamic acid are also found. The peptidoglycan type is B2 $\gamma$. Wholeorganism sugars are galactose, glucose and mannose. The polar lipid profile is composed of diphosphatidylglycerol, phosphatidylglycerol, an unknown glycolipid, unknown polar lipids and four uncharacterized phospholipids. The predominant fatty acids are 12-methyltetradecanoic, 14methylhexadecanoic and 13-methyltetradecanoic acids. The main menaquinones are MK-11 and MK-12. Representative

Table 1. Characteristics that enable Agrococcus casei sp. nov. to be distinguished from the type strains of Agrococcus species

Taxa: 1, A. casei LMG 22410 ${ }^{\mathrm{T}}$, LMG 22411, LMG 22330 and LMG 22447; 2, A. baldri LMG 23057 ; 3, A. citreus LMG 23056 4, A. jenensis LMG $23058^{\mathrm{T}}$; 5, A. lahaulensis DSM $17612^{\mathrm{T}}$.

\begin{tabular}{|lccccc|}
\hline Characteristic & $\mathbf{1}$ & $\mathbf{2}$ & $\mathbf{3}$ & $\mathbf{4}$ & $\mathbf{5}^{\star}$ \\
\hline Aesculin hydrolysis & - & + & + & + & - \\
Degradation of: & & & & & \\
$\quad$ Tributyrin & - & + & + & + & $\mathrm{ND}$ \\
Tween 20 & - & - & - & + & $\mathrm{ND}$ \\
Tween 80 & + & + & + & - & $\mathrm{ND}$ \\
Acid production from: & & & & & \\
Cellobiose & - & + & $+\dagger$ & + & - \\
Fructose & - & - & + & + & + \\
Glucose & + & + & $+\dagger$ & - & $\mathrm{ND}$ \\
Maltose & - & + & $+\dagger$ & - & - \\
Mannitol & - & + & + & + & - \\
Mannose & + & - & - & - & $\mathrm{ND}$ \\
Sucrose & - & + & - & - & - \\
Trehalose & - & + & $+\dagger$ & - & + \\
\hline
\end{tabular}

${ }^{\star}$ Data taken from Mayilraj et al. (2006). ND, Not determined. $\dagger$ Data not in line with Wieser et al. (1999). 
strains were isolated from the surfaces of smear-ripened cheeses.

The type strain is $\mathrm{R}-17892 \mathrm{t} 2^{\mathrm{T}}$ (=DSM $18061^{\mathrm{T}}=\mathrm{LMG}$ $22410^{\mathrm{T}}$ ), isolated from the surface of Gubbeen cheese. The DNA G $+\mathrm{C}$ content of the type strain is $65 \mathrm{~mol} \%$.

\section{Acknowledgements}

This study was carried out with financial support from the European Union [project QLK-CT-2001-02208: Biodiversity and anti-listerial activity of surface microbial consortia from Limburger, Reblochon, Livarot, Tilsit and Gubbeen cheese. Acronym: SCM (Smear cheese microflora)].

\section{References}

Bockelmann, W. \& Hoppe-Seyler, T. (2001). The surface flora of bacterial smear-ripened cheeses from cows' and goats' milk. Int Dairy J 11, 307-314.

Brennan, N. M., Brown, R., Goodfellow, M., Ward, A. C., Beresford, T. P., Vancanneyt, M., Cogan, T. M. \& Fox, P. F. (2001a). Microbacterium gubbeenense sp. nov., from the surface of a smearripened cheese. Int J Syst Evol Microbiol 51, 1969-1976.

Brennan, N. M., Brown, R., Goodfellow, M., Ward, A. C., Beresford, T. P., Simpson, P. J., Fox, P. F. \& Cogan, T. M. (2001b). Corynebacterium mooreparkense sp. nov. and Corynebacterium casei sp. nov., isolated from the surface of a smear-ripened cheese. Int J Syst Evol Microbiol 51, 843-852.

Brennan, N. M., Ward, A. C., Beresford, T. P., Fox, P. F., Goodfellow, M. \& Cogan, T. M. (2002). Biodiversity of the bacterial flora on the surface of a smear cheese. Appl Environ Microbiol 68, 820-830.

Carnio, M. C., Eppert, I. \& Scherer, S. (1999). Analysis of the bacterial surface ripening flora of German and French smeared cheeses with respect to their anti-listerial potential. Int $J$ Food Microbiol 47, 89-97.

Collins, M. D. \& Kroppenstedt, R. M. (1987). Structures of the partially saturated menaquinones of Glycomyces rutgersensis. FEMS Microbiol Lett 44, 215-219.

Cowan, S. T. (1974). Cowan and Steel's Manual for the Identification of Medical Bacteria, 2nd edn. London: Cambridge University Press. Eliskases-Lechner, F. \& Ginzinger, W. (1995). The bacterial flora of surface-ripened cheese with special regard to coryneforms. Lait 75, 571-584.

Felsenstein, J. (1985). Confidence limits on phylogenies: an approach using the bootstrap. Evolution 39, 783-791.

Felsenstein, J. (1993). PHYLIP (phylogenetic inference package), version 3.5c. Distributed by the author. Department of Genome Sciences, University of Washington, Seattle, USA.

Fitch, W. M. \& Margoliash, E. (1967). Construction of phylogenetic trees: a method based on mutation distances as estimated from cytochrome $c$ sequences is of general applicability. Science 155, 279-284.

Gevers, D., Huys, G. \& Swings, J. (2001). Applicability of rep-PCR fingerprinting for identification of Lactobacillus species. FEMS Microbiol Lett 205, 31-36.

Gordon, R. E. (1968). The taxonomy of soil bacteria. In The Ecology of Soil Bacteria, pp. 293-321. Edited by T. R. G. Gray \& D. Parkinson. Liverpool: Liverpool University Press.

Gordon, R. E. \& Mihm, J. M. (1957). A comparative study of some strains received as nocardiae. J Bacteriol 73, 15-27.
Gordon, R. E. \& Mihm, J. M. (1962). Identification of Nocardia caviae (Erikson) nov. comb. Ann N Y Acad Sci 98, 628-636.

Groth, I., Schumann, P., Weiss, N., Martin, K. \& Rainey, F. A. (1996). Agrococcus jenensis gen. nov., sp. nov., a new genus of actinomycetes with diaminobutyric acid in the cell wall. Int J Syst Bacteriol 46, 234-239.

Hugh, R. \& Leifson, E. (1953). The taxonomic significance of fermentative versus oxidative metabolism of carbohydrates by various Gram-negative bacteria. J Bacteriol 66, 24-26.

Irlinger, F., Bimet, F., Delettre, J., Lefevre, M. \& Grimont, P. A. D. (2005). Arthrobacter bergerei sp. nov. and Arthrobacter arilaitensis sp. nov., novel coryneform species isolated from the surfaces of cheeses. Int J Syst Evol Microbiol 55, 457-462.

Jukes, T. H. \& Cantor, C. R. (1969). Evolution of protein molecules. In Mammalian Protein Metabolism, vol. 3, pp. 21-132. Edited by H. N. Munro. New York: Academic Press.

Kim, S. B., Falconer, C., Williams, E. \& Goodfellow, M. (1998), Streptomyces thermocarboxydovorans sp. nov. and Streptomyces thermocarboxydus sp. nov., two moderately thermophilic carboxydotrophic species from soil. Int J Syst Bacteriol 48, 59-68.

Kluge, A. G. \& Farris, F. S. (1969). Quantitative phyletics and the evolution of anurans. Syst Zool 18, 1-32.

Komagata, K. \& Suzuki, K. I. (1987). Lipid and cell-wall analysis in bacterial systematics. Methods Microbiol 19, 161-206.

Kroppenstedt, R. M. (1985). Fatty acid and menaquinone analysis of actinomycetes and related organisms. In Chemical Methods in Bacterial Systematics, pp. 173-179. Edited by M. Goodfellow \& D. E. Minnikin. London: Academic Press.

Lin, Y. C., Uemori, K., De Briel, D. A., Arunpairojana, V. \& Yokota, A. (2004). Zimmermannella helvola gen. nov., sp. nov., Zimmermannella alba sp. nov., Zimmermannella bifida sp. nov., Zimmermannella faecalis sp. nov. and Leucobacter albus sp. nov., novel members of the family Microbacteriaceae. Int J Syst Evol Microbiol 54, 1669-1676.

MacKenzie, S. L. (1987). Gas chromatographic analysis of amino acids as the N-heptafluorobutyryl isobutyl esters. J Assoc Off Anal Chem 70, 151-160.

Mayilraj, S., Suresh, K., Schumann, P., Kroppenstedt, R. M. \& Saini, H. S. (2006). Agrococcus lahaulensis sp. nov., isolated from a cold desert of the Indian Himalayas. Int J Syst Evol Microbiol 56, $1807-1810$.

Mesbah, M., Premachandran, U. \& Whitman, W. B. (1989). Precise measurement of the $\mathrm{G}+\mathrm{C}$ content of deoxyribonucleic acid by high-performance liquid chromatography. Int J Syst Bacteriol 39, 159-167.

Minnikin, D. E., O'Donnell, A. G., Goodfellow, M., Alderson, G., Athalye, M., Schaal, K. \& Parlett, J. H. (1984). An integrated procedure for the extraction of bacterial isoprenoid quinones and polar lipids. J Microbiol Methods 2, 233-241.

Pitcher, D. G., Saunders, N. A. \& Owen, R. J. (1989). Rapid extraction of bacterial genomic DNA with guanidium thiocyanate. Lett Appl Microbiol 8, 151-156.

Piton-Malleret, C. \& Gorrieri, M. (1992). Nature et variabilité de la flore microbienne dans la morge des fromages de Compté et de Beaufort. Lait 72, 143-164 (in French).

Pot, B., Vandamme, P. \& Kersters, K. (1994). Analysis of electrophoretic whole-organism protein fingerprints. In Modern Microbial Methods (Chemical Methods in Prokaryotic Systematics Series), pp. 493-521. Edited by M. Goodfellow \& A. G. O’Donnell. Chichester: Wiley.

Saitou, N. \& Nei, M. (1987). The neighbor-joining method: a new method for reconstructing phylogenetic trees. Mol Biol Evol 4, 406-425. 
Sambrook, J. \& Russell, D. W. (2001). Molecular Cloning: a Laboratory Manual, 3rd edn. Cold Spring Harbor, NY: Cold Spring Harbor Laboratory.

Schaal, K. P. (1985). Identification of clinically significant actinomycetes and related bacteria using chemical techniques. In Chemical Methods in Bacterial Systematics, pp. 359-381. Edited by M. Goodfellow \& D. E. Minnikin. London: Academic Press.

Schleifer, K. H. (1985). Analysis of the chemical composition and primary structure of murein. Methods Microbiol 18, 123-156.

Schleifer, K. H. \& Kandler, O. (1972). Peptidoglycan types of bacterial cell walls and their taxonomic implications. Bacteriol Rev 36, 407-477.

Sierra, G. (1957). A simple method for the detection of lipolytic activity of micro-organisms and some observations on the influence of contact between cells and fatty substrates. Antonie van Leeuwenhoek 23, 15-22.

Uchida, K., Kudo, T., Suzuki, K. \& Nakase, T. (1999). A new rapid method of glycolate test by diethyl ether extraction, which is applicable to a small amount of bacterial cells of less than one milligram. J Gen Appl Microbiol 45, 49-56.

Valdés-Stauber, N., Scherer, S. \& Seiler, H. (1997). Identification of yeasts and coryneform bacteria from the surface microflora of brick cheeses. Int J Food Microbiol 34, 115-129.

Versalovic, J., Schneider, M., de Bruijn, F. J. \& Lupski, J. R. (1994). Genomic fingerprinting of bacteria using repetitive sequence-based polymerase chain reaction. Methods Mol Cell Biol 5, 25-40.

Wieser, M., Schumann, P., Martin, K., Altenburger, P., Burghardt, J., Lubitz, W. \& Busse, H.-J. (1999). Agrococcus citreus sp. nov., isolated from a medieval wall painting of the chapel of Castle Herberstein (Austria). Int J Syst Bacteriol 49, 1165-1170.

Williams, S. T., Goodfellow, M., Alderson, G., Wellington, E. M. H., Sneath, P. H. A. \& Sackin, M. J. (1983). Numerical classification of Streptomyces and related genera. J Gen Microbiol 129, 1743-1813.

Zlamala, C., Schumann, P., Kämpfer, P., Rosselló-Mora, R., Lubitz, W. \& Busse, H.-J. (2002). Agrococcus baldri sp. nov., isolated from the air in the 'Virgilkapelle' in Vienna. Int J Syst Evol Microbiol 52, 1211-1216. 